\title{
THE ENTREPRENEURIAL DEVELOPMENT OF WOMEN IN EU: GEO-ECONOMIC FACTORS IN STARTING A BUSINESS
}

\author{
Alexandra-Lucia POPa* \\ a) Babeș-Bolyai University, Faculty of Economics and Business Administration, \\ Cluj-Napoca, Romania
}

Please cite this article as:

Article History:

Pop, A.L., 2018. The entrepreneurial development

Received: 15 October 2018 of women in EU: geo-economic factors in starting a Accepted: 17 November 2018 business. Review of Economic Studies and Research Virgil Madgearu, 11(2), pp.91-107. doi: 10.24193/RVM.2018.11.28.

Abstract: The purpose of this research paper is to identify the geo-economic factors which determine women to start a new business in their country. We used World Bank's Enterprise Survey data to analyze the evolution of new companies created by women in European Union, between 2011-2017, and which are the most important factors for female to start a business. Panel analysis was used to determine the important factors of the country's economy which influence female to start a new business. The results show a statistically significant model consisting of economic factors (number of procedures, days of starting new business, cost, profit taxes and minimum capital) which determine women to become an entrepreneur. Variables correlate and negatively influence the number of starting business, but bureaucracy, defined such as procedures, has the most negatively impact.

Key words: start-up; new firms; women entrepreneurship; European Union JEL Classification: M13; L26; F23

(C) 2018 Alma Mater Publishing House. All rights reserved.

* Corresponding author. E-mail address: popzalexandra@gmail.com. 
Review of Economic Studies and Research Virgil Madgearu, 2018, 11(2)

\section{References}

1. Agboola, M.G., 2011. Environment Factor and Entrepreneurship development in Nigeria. Journal of Sustainable Development in Africa, 13(4), pp.166-76.

2. Akinruwa, T.E., Awolusi O.D. and Ibojo, B.O., 2013. Determinants of Small and Medium Enterprises (SMEs) Performance in Ekiti State, Nigeria: A Business Survey Approach. European journals of humanities and social sciences, 27(1), pp. 1397-413.

3. Anwar, M.U. and Rashid, A.G., 2012. Female Entrepreneurs - A Review of the Literature and Proposed Conceptual Framework. Institute of Business Administration (IBA), Karachi, Proceedings of 2nd International Conference on Business Management, pp.1-30.

4. Alam, S.S., Jani, M.F.M. and Omar, N.A., 2011. An Empirical Study of Success Factors of Women Entrepreneurs in Southern Region in Malaysia. International Journal of Economics and Finance, 3(2), pp.166-75.

5. Alvandi, S., 2015. Investigating Effective Obstacles on Iranian Women Entrepreneurship. International Journal Of Humanities And Cultural Studies, pp.440-50.

6. Baker, T., Aldrich, H. E. and Liou, N.,1997. Invisible entrepreneurs: The neglect of women business owners by mass media and scholarly journals in the United States. Entrepreneurship and Regional Development, 9(3), pp. 221-38.

7. Borenstein, M., Hedges, L. and Rothstein, H., 2007. Meta-Analysis, Fixed effect vs. random effects, [online] Available at: <http://www. Meta-Analysis.com > [Accessed 18.09.2018].

8. Cantwell, M., 2014. 21st Century Barriers to Women's Entrepreneurship. Majority Report of the U.S. Senate Committee on Small Business and Entrepreneurship, 1(1), pp.1-37.

9. Carter, S. and Rosa, P., 1998. The financing of male-and femaleowned businesses. Entrepreneurship \& Regional Development, 10(3), pp.225-42.

10. Dalborg, C., Friedrichs, Y. and Wincent, J., 2015. Risk perception matters: why women's passion may not lead to a business startup. International Journal of Gender and Entrepreneurship, 7(1), pp.87-104. 
Pop, The Entrepreneurial Development of Women in EU...

11. Estrin, S., and Mickiewicz, T., 2011. Institutions and female entrepreneurship. Small Business Economics. 37 (4), pp.397-415.

12. Fairlie, R.W., Reedy, E.J., Morelix, A. and Russell, J., 2016. The Kauffman Index startup activity. National Trends. [online] Available at: <https://www.kauffman.org/ /media/kauffman_org/microsites/ kauffman_index/startup_activity_2016/kauffman_index_startup_ activity_national_trends_2016.pdf $>$ [Accessed 10.08.2018].

13. Gatewood, E.J., Brush, C.G., Carter, N.M., Greene, P.G. and Hart, M.M., 2004. Women Entrepreneurs, Growth, and Implications for the Classroom. Coleman Foundation White Paper Series United States Association for Small Business and Entrepreneurship. [online] Available at: <http://citeseerx.ist. psu.edu/viewdoc/download?doi=10.1.1.210.3001\&rep=rep1\& type $=$ pdf $>$ [Accessed 25.08.2018].

14. Global Entrepreneurship Monitor, 2016. Global Report 2016/2017, [online] Available at: <https://www.gemconsortium.org/ report/49812> [Accessed 10.09.2018].

15. Gerba, Y.T. and Viswanadham, P., 2016. Performance measurement of small scale enterprises: Review of theoretical and empirical literature. International Journal of Applied Research, 2(3), pp.531-35.

16. Chong, G.H., 2008. Measuring performance of small-and medium sized enterprises: the grounded theory Approach. Journals of Business and Public affairs, 2(1), pp.1-10.

17. Harkiolaks, N., and Caracatsani, W., 2011. Challenges Facing Entrepreneur in Nigeria. Emerald Group Publishing Ltd., 34 (2), pp. 221-36.

18. Khyareh, M.M., 2018. Determinants Of Female Entrepreneurship In Iran: An Institutional Approach. Economic Annals, LXIII (216), pp.111-29.

19. March, J.G., and Sutton, R.I., 1997. Organizational performance as dependent variable. Journal of Organizational Science, 8(6), pp.698-706.

20. Navarro, J.P., and Jiménez, A.M., 2016. Moderators elements of entrepreneurship. Gender differences. Suma de Negocios, 7(15), pp.47-53.

21. OECD, 2004. Women's Entrepreneurship: Issues and Policies, [online] Available at: <http://www.oecd.org/cfe/smes/31919215. pdf $>$ [Accessed 05.09.2018]. 
22. Parker, B.J., 2010. A Conceptual Framework for Developing the Female Entrepreneurship Literature, Western Michigan University. Journal of Research on Women and Gender, pp.169-190.

23. Richard, W., 2018. Panel Data 4: Fixed Effects vs Random Effects Models. University of Notre Dame, [online] Available at: <https:// www3.nd.edu/ rwilliam/> [Accessed 12.09.2018].

24. Torres-Reyna, O., 2007. Panel Data Analysis Fixed and Random Effects using Stata (v. 4.2), Data and statistical services. Princeton University, [online] Available at: <https://dss.princeton.edu/ training/ $>$ [Accessed 10.08.2018].

25. Tlaiss, H.A., 2015. Entrepreneurial motivations of women: Evidence from the United Arab Emirates. International Small Business Journal, 33(5), pp. 562-81.

26. Yusuf, L., 2013. Influence of Gender and Cultural Beliefs on Women Entrepreneurs in Developing Economy. Scholarly Journal of Business Administration, 3(5), pp.117-19. 